\title{
PLURALISME, DEMOKRASI DAN KEADILAN SOSIAL DALAM KONSEPSI FIQIH HUMANISTIK ABOU EL FADL
}

\author{
Abid Rohmanu*
}

\begin{abstract}
To make connection between fiqih and humanism is often judged as a subversive. Religion is convinced the only source of morality, then rationality tendency to discover morality - such as humanism - never get a proportional place. Whereas at a certain point religioun is meaned totalitarianly by his follower, there's potency to exploit religion for political and partisan interest that will kill humanistic values. In this context, the existence of religion is important to be reflected in a humanization process, namely a process to place and treat human being more human.

From the above frame work, this assignment will explain the A bou EI Fadl's conception of humanistic fiqih related to pluralism, democracy, and social justice. These three conceptions are "par excellence" humanistic values that often being campaigned by Abou El Fadl. Abou EI Fadl is a scholar who has great attention to establish link between Islam, fiqih and morality.
\end{abstract}

Keywords: Humanism, Pluralism, Democracyi, Social J ustice.

\section{Pendahuluan}

Dalam perjalanan sejarah agama-agama (history of relegions) terdapat dua wajah keagamaan yang kontradiktif. Satu sisi agama telah banyak berperan dalam mempelopori perdamaian, kasih sayang antar sesama dan hal lain yang bersifat kemanusiaan. Akan tetapi di sisi lain, atas nama agama juga telah tertoreh radikalisme dan kejahatan-kejahatan kemanusiaan yang mengerikan, bisa disebut dalam konteks Islam misalnya serentetan aksi teror dalam berbagai bentuknya yang menelan banyak korban jiwa, klaim-klaim kebenaran pemahaman keagamaan, eksklusifitas dalam bentuk pemurtadan atau takfip terhadap kelompok lain, pendegradasian perempuan dan teknis hukuman shariłah yang tidak manusiawi. Hal tersebut diyakini sebagai imbas pola keberagamaan yang bersifat teosentris dan mengabaikan visi humanistik agama. $\mathrm{H}$ al tersebut kontradiktif dengan klaim bahwa beragama adalah untuk kemaslahatan manusia sebagaimana ia diturunkan untuk merealisasikan rahmah li al-'alamin.

Fiqih sebagai set panduan tata laku yang bersifat praktis sering kali dijadikan alat legitimasi eksklusifitas dan radikalisme sebagaimana dilakukan kelompok puritan. $\mathrm{H}$ al ini bersifat kontraproduktif bagi penyemaian dan penyuburan fiqih sebagai alat transformasi sosial sebagaimana didengungkan oleh proyek reformasi fiqih (Islamic legal reform). Fiqih sebagai transformative tool mengisyaratkan adanya karakter egaliter, humanis dan kosmopolit pada disiplin ini. Meminjam kerangka ilmu sosial profetik Kuntowijiyo, keilmuan sosial - termasuk di dalamnya keilmuan agama dan hukum - tidak boleh berpuas diri dengan memahami dan menjelaskan realitas sosial-keagamaan kemudian memaafkannya, akan tetapi lebih jauh dari itu; mengemban tugas transformasi menuju cita-cita yang diidealkan masyarakat. Karena itu, kemudian ia membagi wilayah penelitian ilmu sosial profetik menjadi tiga; persoalan humanisme (al-'amr bi al-ma'ruA

*Fakultas Syari'ah Sekolah Tinggi Agama Islam (STAIN) Ponorogo 
selain persoalan liberasi (al-nahy 'an al-munkar) dan transendensi. ${ }^{1}$ Salah satu persoalan yang menghadang humanisme sebagai bagian dari ISP adalah agresivitas dan aksi-aksi yang bersifat dehumanistik dalam segala bentuknya.

Dalam kerangka pemikiran di atas, penting untuk mempertautkan disiplin fiqih dengan wacana humanisme. Humanism dalam terminologi renaissance sering kali dideskripsikan dalam terma etis; penekanan pada manusia dan martabatnya. Menurut Aulus Gellius, humanisme dalam pengertian umum berarti philantropia, yakni kecendrungan pada spirit persahabatan dan rasa nyaman terhadap semua manusia tanpa pembedaan. ${ }^{2}$ Pemaduan antara aspek fiqih dengan humanism tersebut telah diprakarsai antara lain oleh sosok Abou El Fadl. Abou El Fadl adalah pemikir dan praktisi yang banyak mendekati hukum Islam dari perspektif moralitas dan humaniti.

Karenanya, artikel ini akan mencoba menguak bagaimana konsepsi fiqih humanistik A bou El Fadl berkaitan dengan nilai pluralisme, demokrasi dan keadilan sosial. Setelah itu juga akan ditelusuri lebih jauh bagaimana pengaruh setting sosial budaya yang mengitari Abou El Fadl terhadap pemikiran dan konsepsi fiqhiyahnya. Di dalam wacana sosiologi pengetahuan, pemikiran dan ide selalu berkelindan dengan kondisi sosial budaya di mana pemikiran dan ide diproduksi. ${ }^{3}$ Pemikiran dan pengetahuan juga selalu mengisyaratkan kepentingan; kepentingan untuk mendobrak dominasi atau, bahkan melanggengkan dominasi.

\section{Mengenal Abou EI Fadl}

Khaled Abou El Fadl yang disebut-sebut sebagai an enlightened paragon of liberal Islam ${ }^{4}$ adalah pemikir sekaligus aktivis terkemuka era modern dalam bidang hukum Islam, Imigrasi, HAM dan hukum keamanan nasional dan internasional. Abou El Fadl dilahirkan di Kuwait pada tahun 1963 dari kedua orang tua yang berasal dari Mesir. la tumbuh besar di Mesir, akan tetapi kemudian ia hijrah ke Amerika bahkan selanjutnya ia dinaturalisasikan menjadi warga negara Amerika. Abou El Fadl kecil dikenal sebagai anak yang cerdas, Usia 12 tahun sudah hafal al-Qur'an. Semasa kecil selain aktif mengikuti kelas al-Qur'an dan Sharisdi masjid al-Azhar dia juga melahap habis semua koleksi buku orang tuanya yang berprofesi sebagai pengacara. Dia juga tekun belajar kepada para shaykh, di antaranya Muhammad al-G hazali (w.1995). Dalam pengakuannya ia sempatmenjadi pengikut setia faham puritan Wahabi semasa di Mesir. Bayangbayang puritanisme tetap melekat pada dirinya hingga dia menyelesaikan Barchelor of Art-nya dengan yudicium cum laude di Yale University pada $1986 .{ }^{5}$

Abou EI Fadl adalah profesor hukum Islam di UCLA (University of California Los Angeles) School of Law. Ia juga pernah mengajar hukum Islam di Texas University, Yale Law School dan

\footnotetext{
'Lihat Kuntowijoyo, Islam sebagai Ilmu; Epistemologi, M etodologi dan Etika (Yogyakarta: Tiara Wacana, 2006), 99. ${ }^{2}$ Peter Levine, Nietzsche and the Modern C risis of the H umanities (New York: State University of N ew York Press, 1995), 19.

${ }^{3}$ Fuad Baali dan Ali Wardi, Ibn Khaldun And Islamic Thought-Styles; A Social Perspective (Massachusetts: G .K. $\mathrm{H}$ all and Co. Boston, 1981), Irving M. Zeitlin, Ideology and Development of Sociological Theory (London: PrenticeHall, 1981), 230.

${ }^{4}$ Nadirsyah Hosen, "Pujian dan Kesaksian" dalam Khaled M. Abou El Fadl, Atas Nama Tuhan; dari Fikih Otoriter ke Fikih O to ritatif , a Pent. R. cecep Lukman Yasin (J akarta: Serambi, 2004).

5Teresa Watanabe, “Battling Islamic Puritans," dalam Los Angeles Times (2 J anuari 2002).
} 
Princeton University. Selain itu ia adalah American lawyer, Dewan Pengurus Human Right Watch, dan ditunjuk Presiden Bush sebagai anggota komisi International Religious Freedom. ${ }^{6}$ Di selasela kesibukannya, Abou EI Fadl menyempatkan dirinya memberikan fatawa terkait isu-isu hukum Islam dan H AM. ${ }^{7}$

Riwayat akademisnya dimulai dari Yale University (B.A.), University of Pennsylvania Law School (J .D.) dan Princeton U niversity (M.A./Ph. D.). Abou El Fadl adalah mahasiswa berprestasi, di program doktornya umpamanya, ia mendapatkan nilai kumulatif yang tinggi dan memenangkan disertasi terbaik Rebellion and Violence in Islamic Law. Sebelumnya ia juga pernah mendalami studi keislaman di Mesir dan Kuwait. Pengetahuannya tentang tradisi klasik dan perjumpaannya dengan tradisi intelektual Amerika yang concern pada kebebasan, toleransi, HAM, dan humanitas menjadikan Abou El Fadl kritis terhadap interpretasi keagamaan yang bersifat dehumanistik. Grand wacananya tentang sisi moralitas Islam sebelum peristiwa 11 September dianggap hanya sebagai wacana esoteris Islam belaka. Akan tetapi setelah peristiwa tersebut, lewat artikelnya What become tolerance in Islam? ide-idenya mendapat banyak apresiasi. $^{8}$

Senjata utama Abou El Fadl adalah buku. Buku-bukunya ${ }^{9}$ menunjukkan betapa luas dan dalam tradisi intelektual Islam ${ }^{10}$, dan itu cukup membentuk pribadi Abou EI Fadl ketika berhadapan dengan persoalan toleransi dan pluralisme. la pernah mengatakan bahwa ia tidak jatuh cinta dengan pengetahuan dan pemikiran analitis bahkan setelah tiba di Barat. Akan tetapi spiritnya terhadap pengetahuan, buku dan penelitian berasal dari jantung Islam sendiri. ${ }^{11}$

Abou EI Fadl juga merupakan penulis yang produktif. Tulisan-tulisannya berkisar tentang tema universal moralitas dan kemanusiaan. Karya-karyanya dalam bentuk buku adalah; Speaking in Go'd Name: Islamic Law, Authority and Women (Oneworld Press, Oxford, 2001); Rebellion and Violence in Islamic Law (Cambridge University Press, 2001); And God Knows the Soldiers: The Authoritative and Aunthoritarian in Islamic Discoursees (UPA/Rowman and Littlefield, 2001); Islam and the Challenge of Democracy (Princeton University Press, 2004); The Place of Tolerance in Islam (Beacon Press, 2002); Conference of the Books: The Search for Beauty in Islam (University Press of Amerika/Rowman and Littlefield, 2001). ${ }^{12}$

\section{${ }^{6}$ lbid.,}

${ }^{7}$ Fatwa-fatwa Abou EI Fadl secara on line bisa dilihat di http://www.scholarofthehouse.org/oninma.html, (A kses 31/ 12/2007).

${ }^{8}$ Teresa Watanabe, "Battling"

${ }^{9} \mathrm{~B} u k u-b u k u$ Abou EI Fadl menghiasi dinding-dinding rumahnya dan juga mengisi ruangan kosong lantai dua rumahnya. la menganggarkan tiap tahunnya 60 ribu dolar untuk buku. Koleksinya lebih dari 40.000 volume, terdiri dari hukum, teologi, sosiologi, filsafat, sejarah dan sastra. Lihat, Teresa Watanabe, "Battling.. "

${ }^{10} \mathrm{Kh}$ ususnya berkaitan dengan literatur Islam, Abou EI Fadl mempunyai koleksi 10.000 volume tentang hukum Islam dan ia masih merencanakan untuk membeli buku/kitab klasik lainnya. Di antara koleksinya sebagian berumur 8 abad, termasuk karya-karya dari mazhab hukum Islam Sunni dan Shi'i. Lihad Ibid.

${ }^{11}$ Lihat The Daily Texan on Line.

${ }^{12}$ Selain dalam bentuk buku, karya-karyanya lebih banyak bertebaran dalam jurnal-jurnal Internasional. Lihat selengkapnya dalam http://www.scholarofthehouse.org. Sebagian besar karyanya sudah diterjemahkan ke dalam bahasa Indonesia, antara lain: A tas Nama Tuhan; Dari Fikih O toriter ke Fikih Otoritatif (Penerbit Serambi), M elawan Tentara Tuhan (Penerbit Serambi), Musyawarah Buku (Penerbit Serambi), Cita dan Fakta Toleransi Islam; Puritanisme versus Pluralisme (Penerbit 'A rsy-Mizan), Islam dan Tantangan Demokrasi (Penerbit Ufuk). Selain itu, pikiran-pikiran Abou EI Fadl - sebagian besar sama dengan tema-tema buku-bukunya - juga bertebaran di puluhan jurnal akademis internasional. 
Dalam tulisan-tulisannya, ia piawai menguraikan nilai-nilai Islam klasik dalam konteks modern. Tulisan-tulisan dan gagasan-gagasan Abou El Fadl yang kritis dan membongkar otoritarianisme tafsir keagamaan membuat kebanyakan Ayatullah, Shaykh dan para pengikutnya "gerah" dan menganggapnya sebagai koruptor dari Amerika yang paling berbahaya terhadap Islam. Tidak heran bila buku-bukunya dilarang masuk Saudi Arabia, sebagaimana Mesir, negara asalnya, juga menolak aplikasi visanya.

\section{Konsepsi Humanisme}

Humanism secara etimologis mempunyai dua kisaran makna; pertama, sistem pemikiran yang bercorak rasional dan lebih berorientasi pada human being daripada yang bersifat divine atau supernatural. Kedua, humanism juga mengacu pada gerakan budaya renaissance yang mempunyai interest pada tradisi pemikiran Yunani dan Romawi dan berseberangan dengan paham Skolastik abad pertengahan. ${ }^{13}$ "H umanisme" adalah salah satu konsep dalam sejarah intelektual yang sering digunakan dalam berbagai bidang, khususnya filsafat, pendidikan dan literatur. Berdasar makna etimologis yang longgar di atas dan penerapannya dalam berbagai bidang, 'humanisme' mempunyai varian makna sesuai bidang masing-masing, dan konteks historis yang melatar-belakanginya. Pada masa pencerahan (mulai pertengahan pertama abad ke-15) misalnya, humanisme lebih banyak dipahami sebagai proyek membangun kehidupan manusia dan masyarakat berdasar tatanan dan aturan akal budi. Walaupun begitu, variasi makna humanisme disatukan oleh benang merah persamaan, yaitu konsen pada nilai-nilai kemanusiaan dan harkat martabat manusia. ${ }^{14}$

H umanisme biasanya dipertentangkan dengan skolatisisme. Paham yang terakhir ini lebih mengarah pada ajaran positivism-A ristotelian abad pertengahan. Sementara humanism adalah gerakan literer dan program budaya, bukan sebuah sistem filosofis. Walaupun program ini pada akhirnya mempunyai implikasi dan paham filosofis. Titik tekan kajian filsafat kaum humanis era renaissance adalah etika. ${ }^{15}$

Dari uraian di atas dapat dipahami bahwa humanisme tidaklah bertentangan dengan agama sebagaimana klaim kelompok puritan Islam. H umanisme tidak bersifat religious atau antireligius, melainkan sebuah orientasi literer dan akademik yang dipelajari untuk menyokong keyakinan dan agenda religious. Dalam konteks Islam, humanisme juga dicurigai sebagai bias Barat dan ditiupkan untuk menggoyahkan keyakinan Islam, karena humanism dianggap menafikan agama. Ini tidak berbeda dalam konteks Kristen. G iovanni Dominici, seorang Imam Dominikan, pernah mengecam studi yang diakukan oleh orang-orang Kristen terhadap literatur kuno atau filsafat karena hal tersebut dianggap sebagai kemerosotan ruhani. Sebaliknya, J acques Letevre dan Desiderius melihat studi humanistik sebagai bagian dari pembaharuan religious yang terfokus pada karya-karya klasik sebagai inspirasi. ${ }^{16}$ Ya, agama tidak selalu bertentangan dengan

\footnotetext{
${ }^{13}$ Lihat, Tony Smith, Concise Oxford English Dictionary Eleventh Edition, Software atau digital dictionary berdasar text: Oxford University Press, 2004.

${ }^{14}$ Thomas Hidya Tjaya, Humanisme dan Skolatisisme; Sebuah Debat (Yogyakarta: Kanisius, 2004), 17.

${ }^{15}$ Ibid., 20-21.

${ }^{16}$ Lihat, Ibid., 70-71.
} 
humanisme. Ajaran keagamaan yang dimaknai secara humanis dan rasional akan melapangkan citra positif bagi peran agama yang apresiatif dengan konteks kemanusiaan. Demikian halnya hubungan antara Islam dan humanisme. Ali Shari'ati memasukkan agama (termasuk Islam) sebagai salah satu mazhab atau aliran humanisme. ${ }^{17}$

J ohn L. Kraemer menuliskan bahwa sejarah Islam mengalami renaissance lebih awal, yakni abad ke-9 sampai ke-10 M. Renaissance dalam masyarakat Islam juga juga memunculkan gerakan humanisme dan skolatisisme. Mirip dengan humanisme di Barat, humanisme Islam mempunyai karakter-karakter sebagai berikut. ${ }^{18}$

1. Pengadopsian filsafat klasik sebagai cita-cita pendidikan dan kebudayaan.

2. Konsepsi tentang persaudaraan dan kesatuan seluruh umat manusia

3. Keramahan dan cinta kasih sesama umat

4. Keyakinan bahwa al-'ulum al-awaił adalah warisan bersama.

Kuntowijoyo menegaskan bahwa humanisme merupakan perspektif di mana seseorang dihormati sebagai persona, sebagai manusia seutuhnya. Humanisme berkeyakinan bahwa "hal paling buruk yang kita lakukan terhadap orang lain adalah kekejaman". Kekejaman dalam bentuk apapun tak pernah dibenarkan oleh agama. Dus, inti sikap humanis adalah menolak untuk bertindak kejam atas nama apapun, termasuk atas nama agama. Seorang yang humanis adalah seorang yang solider dengan orang-orang miskin, lemah dan tertindas dan ia menentang segala bentuk ketidakadilan. ${ }^{19}$ Inti sikap humanis tersebut sebenarnya bukan sesuatu yang baru dalam Islam. Banyak teks-teks keagamaan dalam Islam yang mempunyai spirit humanistik sebagaimana dinyatakan Kuntowijoyo. Dan semua agama tentu mempunyai klaim menyuarakan nilai humanisme. Akan tetapi kelemahannya adalah bahwa spirit moralitas dalam agama belum ditarik dalam wacana filsafat etik sehingga spirit tersebut terkesan mandeg vis a vis dinamika kehidupan manusia yang kompleks. Etika menurut Kuntowijoyo sangat diperlukan oleh tokoh keagamaan untuk merespon peristiwa-peristiwa hukum baru yang belum ter-cover dalam teks yang membutuhkan solusi hukum. Di sisi yang lain ia menegaskan perlunya obyektifikasi Islam, yakni penerjemahan nilai-nilai internal ke dalam kategori-kategori obyektif. Obyektifikasi tambahnya, adalah perbuatan rasional-nilai yang diwujudkan dalam bentuk perbuatan rasional sehingga orang luar pun (non-muslim) dapat menikmatinya tanpa harus setuju dengan nilainilai asal; kesetiakawanan nasional misalnya, merupakan obyektifikasi dari nilai ukhuwwah. ${ }^{20}$

Humanisme pada akhirnya menawarkan kesalehan yang bersifat universal, tidak bersifat formal akan tetapi kosong. Tindakan dan simbol-simbol keagamaan harus mempunyai koherensi dengan realitas batin dan ruhani. Hal ini pararel dengan Abou El Fadl ketika mengkaji tema "autoritatif" dan "authoritarianism" menyatakan bahwa ketaatan dan kesalehan bukan bagian dari kriteria otoritas dalam bidang hukum Islam. ${ }^{21}$ la menyatakan bahwa kriteria otoritas dalam

${ }^{17} \mathrm{http:} / /$ www.sinarharapan.co.id/berita/0310/15/opi01.html, (Akses $13 \mathrm{~J}$ an 2008).

18j ohn L. Kraemer, Renaissance Islam, Terj. Asep Saifullah (Bandung: Mizan, 2003 ), 32.

${ }^{19}$ Franz Magnis-Suseno, Etika Kebangsaan Etika Kemanusiaan (Yogykarta: Kanisius, 2008), 10.

${ }^{20}$ Lebih lengkap uraian tentang objektifikasi Islam silahkan lihat, Kuntowijoyo, Islam sebagai IImu, 62.

${ }^{21}$ Bukannya dua hal ini tidak penting, akan tetapi karena tingkat pengetahuan dan kesalehan tidak terkait dengan dinamika penelitian. Dua hal ini tidak bisa untuk mengevaluasi sebuah tindakan yang berada di luar batas kewenangannya. Tegasnya dua hal tersebut tidak menjamin pemegang otoritas bisa bersifat humanis. Bahkan, 
penelitian hukum Islam meng-cover unsur-unsur moralitas; kejujuran (henesty), ${ }^{22}$ kesungguhan (diligence), ${ }^{23}$ kemenyeluruhan (comprehensiveness), ${ }^{24}$ rasionalitas (reasonableness), ${ }^{25}$ dan pengendalian diri (self-restraint). ${ }^{26}$

\section{Mempertautkan Fiqih dan Humanisme; Belajar dari Abou EI Fadl}

Nilai-nilai humanisme par excellence paling tidak dapat didekodifikasikan menjadi tiga; pluralisme, demokrasi dan keadilan sosial. ${ }^{27}$ Tiga nilai ini menurut penulis relevan untuk ditarik dalam konteks pemikiran fiqih A bou EI Fadl. Izetbegovic mengatakan bahwa humanisme pada intinya merupakan pengakuan terjadap eksistensi dan kebebasan orang lain. ${ }^{28}$ Pluralisme, demokrasi dan keadilan sosial ketiganya merupakan ekspresi dari pengakuan terhadap eksistensi dan kebebasan tersebut.

\section{Pluralisme}

Pluralisme adalah kesediaan untuk menjunjung pluralitas, yakni kesediaan untuk menerima kenyataan bahwa dalam masyarakat ada cara hidup, budaya, dan keyakinan yang berbeda serta kesediaan untuk hidup dan bergaul bersama (ko-eksistensi) serta bekerja sama (ko-operasi). Pluralisme sering kali hanya diwacanakan dalam sikap dan konsepsi teologis dan belum beranjak ke arah tataran praktis, ${ }^{29}$ karena itu gap antara idealita dan realita tetap menganga. Dalam konteks ini, maka kajian pluralisme dari aspek fiqih menemukan relevansinya.

Mengembangkan nilai pluralisme tradisi fiqih bagaimanapun mengisyaratkan kesediaan untuk melakukan interpretasi ulang terhadap khazanah fiqih klasik yang dirumuskan dalam setting sosial budaya yang sama sekali berlainan dengan konteks kekinian. Batu sandungan penerapan nilai pluralisme yang utama adalah berkaitan dengan fiqih interaksi dengan

menurut Abou EI Fadl, kesalehan bisa saja mendorong seseorang untuk melakukan hal yang tidak patut dalam upaya mempertahankan apa yang ia yakini sebagai kehendak Tuhan. Khaled M. Abou EI Fadl, Atas Nama Tuhan; dari Fikih O toriter ke Fikih Otoritatif, Pent. R. Cecep Lukman Yasin (J akarta: Serambi, 2004), 108.

${ }^{22}$ Kejujuran tidak berkaitan dengan penafsiran, tapi penjelasan. Prinsip ini mengasumsikan bahwa pemegang otoritas tidak membatasi, menyembunyikan, dan merekayasa pesan teks untuk maksud berbohong dan menipu. Ibid., 100. ${ }^{23}$ Kesungguhan artinya pemegang otoritas telah berusaha semaksimal mungkin memahami, menyelidiki dan merenungkan pesan teks. Ibid.

${ }^{24}$ Artinya bahwa pemegang oto ritas telah menyelidiki pesan teks secara menyeluruh dan mempertimbangkan semua pesan teks yang relevan. Ibid., 101.

${ }^{25}$ Artinya pemegang otoritas sebagai pembaca teks telah melakukan penafsiraan dan interpretasi secara rasional dengan menggunakan penalaran yang diakui absah secara umum. Ibid.

${ }^{26}$ Artinya pemegang otoritas menunjukkan tingkat kerendahan hati dan pengendalian diri yang layak dalam menjelaskan maksud dan kehendak Tuhan yang terbingkai dalam teks. Konkritnya tidak ada arogansi intelektual bahwa tafsirannya yang paling benar. Ibid., 103.

${ }^{27}$ Ini sebagaimana dilakukan oleh Frans Magnis-Suseno ketika berbicara tentang humanisme dalam konteks etika kebangsaan. Lihat Magnis-Suseno, Etika Kebangsaan, 27.

${ }^{28 ' A l i j a ~ ' A l i ~ I z e t b e g o v i c, ~ ' T h e ~ M e a n i n g ~ o f ~ H u m a n i s m ' ~ d a l a m ~ M a r c e l ~ A . ~ B o i s a r d, ~ H ~ u m a n i s m ~ i n ~ I s l a m ~(K u a l a ~ L u m p u r: ~}$ Islamic Book Trust, 2003), xvi.

${ }^{29} \mathrm{Teologi} / a q i d a h$ adalah prinsip yang mendasari hukum/shari’ah. Keduanya tidak bisa dipisahkan. Mengabaikan aspek syari'ah dan hanya bergelut pada persoalan teologi adalah visi yang tidak bisa dipertanggungjawabkan. Lihat, Mustafa Muhammad Husnayn, al-Siyasah al-J ina'iyah fi al-Tashri' al-Islami (Mekah: Jami'ah al-Imam Muhammad b. Sa'ud al-Islamiiłah, 1984), 12. 
pemeluk agama lain (non-muslim), utamanya konsep fiqih tentang jizyah dan jihad. ${ }^{30}$ Dalam wacana global, bagaimana Islam sering kali dicitrakan sebagai keras dan tidak menghargai eksistensi pemeluk agama lain dengan konsepsi fiqhiyah tradisionalnya yang cenderung mensubordinasikan kelompok agama lain. Menurut Ebrahim Moosa, konsepsi tradisional fiqih berkaitan dengan interaksi muslim dan non-muslim memang tidak dijadikan hukum positif di kebanyakan Negara Islam kontemporer, akan tetapi pandangan bahwa non-muslim merupakan warga negara kelas dua telah menjadi praktek kebudayaan tak tertulis. ${ }^{31}$ Fiqih tradisional bagaimanapun telah menjadi mindset para ulama tradisional dan kelompok puritan kontemporer.

Menurut Abou El Fadl, kebanyakan yuris memilah wilayah menjadi dua kategori; wilayah Islam (dapal-Islam) dan wilayah perang/kufr (dapal-hæarb/dapal-kufr). ${ }^{32}$ Pembagian ini menunjuk pada teritori atau yurisdiksi kekuasaan muslim berhadapan dengan teritori dan yurisdiksi non-muslim. Pembagian yang bersifat dikotomis ini membawa pada konsekuensi psikologis; perasaan perang dan bermusuhan dengan kelompok agama lain. Tiga opsi yang diberikan para Yuris klasik - dan ini menjadi pegangan erat kelompok puritan kontemporer terhadap non muslim berkisar pada tiga hal; masuk Islam, membayar pajak (jizyah) dengan status ahl al-dhimmah, atau perang. . $^{33}$

Tiga opsi tersebut jelas merupakan implikasi dari perasaan superior dan arogansi teologis kelompok puritan yang membawa pada sikap intoleran dan eksklusif. J izyah yang menurut Paul Heck dikembangkan dari tradisi pajak masyarakat Sassanian bagi muslim puritan merupakan bukti material ketundukan non muslim terhadap mereka. ${ }^{34}$ Menurut mereka "jalan lurus" (sirat al-mustaqim) menuju Tuhan sudah fix dengan sistem sharisah (divine law) sebagaimana diinterpretasikan para Yuris klasik. Sistem shariłah tersebut dipedomani tanpa menghiraukan impact-nya terhadap "yang lain", termasuk dalam hal ini aplikasi jizyah. ${ }^{35}$

Kritik Abou El Fadl terhadap konsepsi jizyah tidak hanya terbatas pada penerapannya yang bersifat spesifik terhadap non muslim, akan tetapi juga karena pada dasarnya konsepsi tersebut merendahkan kemanusiaan dan hukum alam. J elas ia secara demonstratif merupakan wujud pelembagaan inferioritas dan humiliasi satu kelompok terhadap kelompok yang lain. J izyah secara kondusif gampang melahirkan sikap arogan dan tidak respek terhadap potensi kemanusiaan non muslim. Sikap arogan ini bila 'dibumbui' dengan pesan normatif teks bisa melahirkan radikalisme dan agresifitas. ${ }^{36}$ Menurut Abou El Fadl, konsepsi ahl al-dhimmah

\footnotetext{
${ }^{30}$ Khalid Abou El Fadl, The Place of Tolerance in Islam; on Reading the Qur'an and - Misreading it. Originally Published in December 2001/J an athttp://bostonreview.mit.edu/BR26.6/elfadl.html

${ }^{31}$ Ebrahim Moosa dalam bukunya, Islam Progresif; Refleksi Dilematis tentang HAM, Modernitas dan Hak-hak Perempuan di dalam Hukum Islam (Yogyakarta: LKiS, 2004), 43.

32 Dalam perkembangannya, khususnya setelah abad ke-10, muncul status wilayah yang disebut dengan dar al-sulh atau dar al-'ahd, yakni wilayah non muslim yang mengikat perjanjian damai dengan wilayah Islam. perang terhadap wilayah ini tidak saja dipandang berdosa, akan tetapi diharuskan mengganti segala kerugiam material. Lihat, Abou El Fadl, Selamatkan Islam dari M uslim Puritan, terj. Helmi M ustofa (J akarta: Serambi, 2006), 272.

33 Ibid., 269 - 270.

${ }^{34}$ Lihat "J izya" dalam http://en. wikipedia.org/wiki// izya (akses 3 J uni 2008)

${ }^{35}$ Khalid Abou El Fadl, The Place of Tolerance in Islam; on Reading the Qur'an and - Misreading it. Originally Published in December 2001/J an athttp://bostonreview.mit.edu/BR26.6/elfadl.html

${ }^{36}$ Lihat "J izya" dalam http://en. wikipedia.org/wiki// izya (akses 3 J uni 2008)
} 
dengan kewajiban membayar pajak adalah bersifat ahistoris bila diterapkan pada era kontemporer yang umumnya banyak wilayah menganut sistem negara bangsa. Konsep ahl al-dhimmah hanya relevan pada saat konsepsi ini dirumuskan, era pertengahan. Pada era pertengahan ini, galibnya minoritas agama atau etnis membayar jizyah atas biaya administrasi, penerapan adat istiadat dan UU mereka. ${ }^{37}$ J izyah juga merupakan konsesi yang diberikan pihak minoritas yang berdiam di teritori Islam atas perlindungan yang diberikan oleh Pemerintah Islam. ${ }^{38}$ Sebagai justifikasinya mereka mengutip makna literal dan temporal alQur'an yang memerintahkan untuk memerangi non muslim hingga mereka membayar jizyah sebagai simbol ketundukan. ${ }^{39}$ Padahal menurut A bou El Fadl konsepsi jizyah al-Qur'a hanya bisa dipahami dengan melibatkan sisi historis yang mengelilingi revelasi teks dan tentunya pesan moralitas al-Qur'an.

$\mathrm{Hal}$ di atas dikuatkan, menurut Abou El Fadl, sinyalemen al-Qur'an bahwa jizyah bukanlah institusi yang harus dimainkan secara absolut. Al-Qur'an mengabsahkan jizyah sebagai respon terhadap sebagian kecil kelompok masyarakat Arab yang bersikap hostile terhadap masyarakat muslim awal. ${ }^{40}$ Pada kenyataannya Nabi saw tidak menerapkan jizyah terhadap setiap non muslim yang mengakui eksistensi dan kedaulatan masyarakat Islam, dan bahkan Nabi kadang kala memberikan sejumlah uang atau bingkisan kepada mereka. Nabi menyebut mereka dengan "mereka yang hatinya telah tunduk". Lebih jauh, 'U mar ketika mengikat perdamaian dengan suku Kristen Arab mengizinkan mereka membayar pajak tahunan (zakat) dan bukan jizyah. Walaupun mereka menolak memeluk Islam, akan tetapi mereka lebih memilih membayar zakat karena merasakan bahwa jizyah mendegradasikan mereka, dan kenyataannya 'U mar mengakomodasi permintaan mereka. ${ }^{41}$

Opsi yang ketiga terhadap non muslim - setelah menolak untuk masuk Islam atau membayar jizyah - adalah perang (fight) atau jihad dalam bahasa muslim puritan. J ihad lebih menunjuk pada doktrin yang bersifat legal (fiqih). Dalam kitab-kitab fiqih klasik biasanya ada bab khusus tentang Book of J ihad, atau dengan nama lain Book of Siyar (law of war) atau Book of J izyah. Subtansi dari bab-bab ini umumnya sama. ${ }^{42}$ Karenanya berbicara tentang jihad adalah berbicara tentang doktrin fiqih.

\footnotetext{
${ }^{37}$ Abou El Fadl, Selamatkan Islam, 257.

${ }^{38} \mathrm{~J} \mathrm{ikalau} \mathrm{pemerintahan} \mathrm{Islam} \mathrm{dianggap} \mathrm{tidak} \mathrm{mampu} \mathrm{melakukan} \mathrm{proteksi} \mathrm{terhadap} \mathrm{mereka,} \mathrm{maka} \mathrm{jizyah} \mathrm{harus}$ dikembalikan. Hal ini sebagaimana dilakukan Khalifah 'U mar yang mengembalikan jizyah kepada suku Kristen A rab ketika 'U mar tidak sanggup memproteksinya dari agresi Bizantium. Lihat Khalid Abou EI Fadl, The Place of Tolerance in Islam; on Reading the Q ur'an and - M isreading it O riginally Published in December 2001/J an at http:/ /bostonreview.mit.edu/BR26.6/elfadl.html

${ }_{39}$ al-Qur'an, 9 (al-Tawbah): 29.

40 Pada masa Nabi saw, legalisasi jizyah diawali dari penghianatan Suku Yahudi Madinah terhadap kesepakatan damai sebagaimana terumuskan dalam Piagam Madinah. Hal ini mengawali perubahan policy Nabi terhadap kelompok Yahudi dan Kristen dengan memberikan penawaran proteksi dengan imbalan jizyah.

${ }^{41}$ Lihat Khalid Abou EI Fadl, The Place of Tolerance in Islam; on Reading the Q ur'an and - Misreading it. O riginally Published in December 2001/J an at http://bostonreview.mit.edu/BR26.6/elfadl.html. Suku Kristen Arabia Utara lebih memilih membayar zakat/shadaqah yang yang bermakna charity walaupun jumlahnya dua kali lipat. Sebaliknya Fred Donner mengungkapkan bahwa sadaqah adalah retribusi untuk suku nomad Arab, sementara jizyah untuk non muslim. Karena sadaqah mengindikasikan status rendah suku nomad, suku Kristen Arab lebih memilih jizyah. Lihat "J izya" dalam http://en. wikipedia.org/wiki/] izya (akses 3 J uni 2008).

42 Michael Bonner, J ihad in Islamic H istory (Princeton: Princeton University Press, 2006), 3.
} 
J ihad menurut Abou EI Fadl adalah doktrin yang paling banyak disalahpahami baik oleh umat Islam sendiri ataupun the other dan sering kali menciderai ide pluralisme. J ihad sebagaimana dapat dipahami dari Abou El Fadl sejatinya kaya makna. J ihad yang secara etimologis bermakna "bekerja keras", "tekun bekerja", "berjuang" dan "mempertahankan" pada dasarnya lebih merujuk pada etika kerja yang kuat secara spiritual dan material. Karena itu tidak bisa dipahami adanya kesalehan, pengetahuan, kebenaran, kesejahteraan dan keadilan tanpa adanya spirit jihad. Dalam hal ini mirip dengan etika kerja Protestan. ${ }^{43} \mathrm{Akan}$ tetapi menurut Abou EI Fadl, jihad utamanya bagi kelompok puritan lebih dipahami sebagai ide "perang suci" (holy war), walaupun memang perang adalah salah satu makna dari konsep jihad.

Persoalannya, menurut Abou EI Fadl, ide perang suci tidak dikenal dalam Islam. Tidak ada oto ritas kelembagaan dalam Islam yang bisa memberikan justifikasi bahwa sebuah perang bernilai suci atau tidak. Dalam teologi Islam, perang tidak pernah bernilai suci secara mutlak - ia bisa dibenarkan atau tidak - dan bila dibenarkan, mereka yang terbunuh dianggap sebagai shuhada's Akan tetapi, penentuan status shuhada'>berada dalam wilayah eksklusif Tuhan. Manusia sama sekali tidak bisa mengukur kedalaman motif dan niat seseorang ${ }^{44} \mathrm{Ibn}$ Khaldun sebagaimana dikutip oleh Bonner, mengklasifikasikan perang menjadi empat macam; pertama, perang antar suku dan famili yang bertetangga; kedua, perang yang dipicu karena kejahatan dan kedengkian sebagaimana suku-suku padang pasir memerangi suku lain untuk motif properti; ketiga, perang yang dalam fiqih disebut dengan jihad; keempat; perang Dinasti terhadap para pembelot dan penghianat. Dari keempat model perang ini, dua yang pertama bukan perang yang absah dan legal, sementara dua yang terakhir adalah perang jihad dan keadilan (hurub al-jihad wa al-'adl). ${ }^{45}$

Karena itu dalam al-Qur'an ada pembedaan antara jihad dan qital: Berbeda dengan qitalyyang lebih bermakna fisik, jihad lebih berorientasi pada spirit dan nilai etis sebagaimana ia dipararelkan dengan etika Protestan. Nuansa fisik jihad terbentuk karena setting sejarah para Yuris abad pertengahan, khususnya abad ke-9 dan ke-10. Sejarah pada era ini mempengaruhi cara baca dan tafsir para Yuris terhadap teks. Sebagaimana penuturan sejarah, pada abad-abad ini - dengan tidak adanya pakta perdamaian - bangsa-bangsa dan dinasti diselimuti perasaan dan situasi perang terus menerus. Untuk menghindarkan invasi, bangsa yang lemah secara militer biasanya melakukan kontrak damai dengan bangsa yang kuat dengan membayar upeti. Dan seandainya ada kontrak perdamaianpun, ia dengan mudah bisa dilanggar oleh penguasa yang ambisius. ${ }^{46}$ Intinya, perang adalah bagian dari kehidupan era itu dan berpengaruh terhadap pemaknaan mereka pada konsep jihad.

Menurut Abou El fadl, jihad tidak pernah bermakna jihad dalam artian yang sesungguhnya bila tidak dikaitkan dengan "sebab moral". Sebab moral tersebut adalah "menghalangi orang lain melakukan korupsi terhadap agama kita" ${ }^{47}$ Agama adalah eksistensi

\footnotetext{
${ }^{43}$ Abou El Fadl, Selamatkan Islam, 265.

${ }^{44}$ Ibid., 267.

${ }^{45}$ Bonner, J ihad, 6.

${ }^{46}$ Abou El Fadl, Selamatkan Islam, 268 - 269.

${ }^{47}$ Lihat http://www.motherjones.com/mojoblog/archives/2007/11/6173_tancredo_go_boo.html
} 
yang bersifat asasi bagi manusia, dan karenanya tidak boleh untuk dilecehkan. Karena itulah Abou El Fadl memaknai wilayah Islam (dapal-Islam) sebagai wilayah manapun di mana keadilan ditegakkan (dapal-'adl) atau wilayah manapun umat Islam bisa dengan merdeka menjalankan agama mereka. Karena itu menurutnya, sejumlah Yuris Klasik telah membagi; wilayah Islam yang sifatnya formal dengan wilayah Islam yang sebenarnya. Wilayah formal Islam menunjuk pada wilayah Islam yang dikendalikan oleh pemimpin yang tidak adil, sedang wilayah Islam sebenarnya menunjuk pada wilayah yang terbebas dari kontrol penguasa zalim dan masyarakat bisa melakukan praktek keagamaan dengan bebas. ${ }^{48}$

2. Demokrasi

Demokrasi selama ini diyakini sebagai sistem politik dan pemerintahan yang elegan dibandingkan dengan sistem yang lain. Ideologi-ideologi politik yang bersifat totaliter - baik itu yang sekuler maupun yang religious - terbukti telah mendiskreditkan sisi-sisi kemanusiaan manusia. Ada dua unsur khas yang dikandung ideologi totaliter; pertama, ketaatan tanpa reserve dan kedua mesin psikologi ideologi, yakni yang mendorong pengikut ideologi tersebut adalah kebencian sebagaimana tercermin dalam ideologi Komunisme dan Nazisme dan ideologi agamis yang mewujud dalam fundamentalisme. Ideologi yang terakhir ini telah menyerobot hak dan kebebasan orang lain karena kebenaran menurut mereka harus ditaati secara mutlak dan merekalah pemilik kebenaran karena klaim bahwa mereka berbicara atas nama Tuhan. ${ }^{49}$

Sementara itu kekuatan moral demokrasi terletak pada ide bahwa penduduk suatu bangsa atau masyarakatlah pemilik kedaulatan yang dalam konteks negara modern mereka mengekspresikan kedaulatan tersebut dengan memilih wakil-wakil yang duduk di dewan atau pemerintahan. Dalam sistem demokrasi, masyarakat adalah sumber hukum. Hukum yang dimaksud adalah yang menyokong hak-hak yang bersifat fundamental yang menjamin eksistensi dan kepentingan individu sebagai bagian dari masyarakat pemilik kedaulatan. Isu kedaulatan inilah, menurut Abou El Fadl, yang bersifat sentral dalam wacana demokrasi. Yuris klasik sebagaimana kelompok puritan berkeyakinan bahwa prinsip kedaulatan dalam sistem demokrasi adalah tidak legitimate, karena Tuhan-lah satu-satunya pemilik kedaulatan dan sumber hukum. Demokrasi dalam hal ini dianggap telah menduakan Tuhan. ${ }^{50}$ Menghadapi tension kedaulatan dalam sistem demokrasi dan Islam ini, Abou El Fadl menampilkan beberapa pendapat yang bersifat rekonsiliatif. Pertama, benar bahwa kedaulatan adalah milik Tuhan, akan tetapi kedaulatan tersebut telah didelegasikan kepada manusia secara total. Kedua, kedaulatan adalah di tangan manusia sepanjang berkaitan dengan masalah-masalah kemanusiaan. Ketiga, manusia adalah pemegang kedaulatan, karena urusanurusan manusia diserahkan pada manusia dan urusan-urusan Tuhan diserahkan pada Tuhan. Pendapat yang terakhir ini menurut A bou EI Fadl, lebih dekat dengan pandangan sekuler. ${ }^{51}$

Demokrasi adalah tantangan dan obyek perdebatan, tidak saja antara dunia Islam dan

\footnotetext{
${ }^{48}$ Abou El Fadl, Selamatkan Islam, 274.

${ }^{49}$ Magnis-Suseno, Etika Kebangsaan, 24.

${ }^{50} \mathrm{Abou}$ El Fadl, Islam and the Challenge of Democracy (Princeton: Princeton University Press, 2004), 4 (Sample Chapter).

${ }^{51}$ Abou El Fadl, Selamatkan Islam, 234.
} 
Barat, akan tetapi internal dunia Islam sendiri. MenurutEsposito, paling tidak ada tiga kelompok yang saling berhadapan terkait dengan wacana demokrasi ini, yakni kelompok sekular, rejeksionis dan kelompok pembaharu. Kelompok sekular menuntut pemisahan agama dan persoalan negara, kelompok rejeksionis (baik moderat atau puritan) menyatakan bahwa bentuk pemerintahan Islam tidak sesuai dengan sistem demokrasi, sementara kelompok pembaharu mencoba merekonsiliasikan Islam dan demokrasi dengan melakukan reinterpretasi terhadap konsep-konsep kunci dalam tradisi Islam, shurałlembaga konsultasi antara rakyat dan pemerintah), ljma'>(konsensus masyarakat), ijtihad (reinterpretasi) dan maslahah (kesejahteraan publik). ${ }^{52}$

Konsep shupasmisalnya, adalah konsep yang terbuka untuk dipikirkan dan dikembangkan ke arah konsep demokrasi dalam pengertian sekarang ini sesuai dengan kebutuhan masyarakat muslim kontemporer. ${ }^{53}$ Perintah shura dalam al-Q ur'an menurut Abou El Fadl merupakan bentuk penandasan tentang tidak dibenarkannya penindasan dan kesewenangan oleh elit despotik. Keputusan -mengacu pada konsep ini- merupakan hasil interaksi demokratis di antara banyak orang. ${ }^{54}$ Dalam sejarah yurisprudensi Islam konsep shura łkonsultasi) ini dilembagakan dalam bentuk ahl al-hall wa al-'aqd. Embrio lembaga ini bermula dari kreasi 'U marb. Khattab ketika memilih beberapa tokoh yang berasal dari varian kelompok untuk duduk dalam suatu lembaga khusus. Lembaga ini berfungsi sebagai pemerintahan sementara pada masa transisi pasca 'U mar dan selanjutnya memilih Khalifah ke-3. Pada perkembangan selanjutnya, lembaga ini berfungsi sebagai lembaga konsultatif bagi khalifah. ${ }^{55}$ Sedangkan konsep ijma' lebih diorientasikan pada upaya menopang ide demokrasi. Selama ini Yuris klasik banyak menggunakan konsep ini dalam konteks yurisprudensi yang eksistensinyapun secara detail masih diperselisihkan. Menurut kaum Moderat sebagaimana diamini Abou El Fadl, ijma' seharusnya tidak dimaknai sebagai konsensus (kebulatan suara), akan tetapi diartikan adanya kelompok mayoritas dalam pengertian yang sederhana. ${ }^{56}$ Sedang konsep ijtihad dan maslahłah (kesejahteraan publik) lebih bersifat umum. Konsep dan aplikasi ijtihad serta kemaslahatan ini menjadi basis citacita demokrasi dalam Islam.

Menurutnya, Persoalan demokrasi dan Islam pada dasarnya adalah persoalan nilai dan moralitas. J ika fokusnya adalah nilai dan moralitas, tegas Abou EI Fadl, tradisi pemikiran politik Islam kaya akan potensi praktis dan interpretatif bagi pengembangan sistem demokrasi. Akan tetapi, tanpa adanya komitmen moral potensi tersebut tidak akan tersentuh atau tidak akan pernah ada sistem demokrasi dalam Islam. Demokrasi hendaknya dipandang sebagai seperangkat etika kebaikan dan untuk menggapai etika yang baik tersebut tidak harus menafikan Islam. ${ }^{57}$

52 Lihat J ohn L. Esposito, a respon to The Place of Tolerance in Islam (O riginally published in the February/March 2002 issue of Boston Review).

${ }^{53}$ al-J abiri, Syuro; Tradisi, Partikularitas dan Universalitas (Yogyakarta: LkiS, 2003), xii.

${ }^{54} \mathrm{~A}$ bou El Fadl, Selamatkan Islam, 230.

${ }^{55}$ Ibid., 231.

56 Ibid., 233.

${ }^{57}$ Abou El Fadl, Islam and the Challenge, 5. 
Al-Qur'an tidak pernah menentukan secara spesifik bentuk pemerintahan, walaupun para Yuris masih saja berdebat tentang bentuk sistem politik Islam. Tetapi al-Qur'an memberikan seperangkat nilai dalam bidang politik dan kemasyarakatan yang bersifat sentral bagi umat Islam. Nilai-nilai tersebut adalah: menggapai keadilan dengan kerjasama sosial dan tolong menolong (al-H ujurat, 49: 13; H ud, 11: 119), menegakkan pemerintahan yang non-autokratik dan pelembagaan rasa kasih sayang, simpati dan empati dalam interaksi sosial (al-An'am, 6: 12, 54; al-Anbiyas, 21: 107; al-N Naml, 27: 77; al-Q as\$s,\} 29: 51; al-J athiyah, 45: 20). ${ }^{58}$

Pada intinya, menurut Abou El fadl, Islam dan demokrasi bisa berko-eksistensi. Akan tetapi hal tersebut tergantung bagaimana umat Islam menginterpretasikan teks keagamaan. Partai Demokrat Kristen di G erman misalnya, dengan interpretasi teks yang bersifat progresif dengan basis moralitas, menyatakan bahwa konsep demokrasi pararel dengan nilai Kristiani. Akan tetapi bila umat mengatakan kedaulatan ada di tangan Tuhan dan kami memerintah atas nama Tuhan, maka demokrasi hanya akan menjadi utopia. Bila seseorang berpretensi menjadi Tuhan, maka demokrasi akan terkebirikan. Demokrasi dalam Islam mengandaikan bahwa tak seorangpun yang bisa merepresentasikan sebagai Tuhan. ${ }^{59}$

Pertanyaannya kemudian adalah, apa peran yang dimainkan oleh shariłah dalam sistem demokrasi. Sharisah dalam konteks negara demokratis menurut A bou El fadl sebatas menjadi panduan moral dan etika. Abou El Fadl berkeyakinan bahwa bimbingan Tuhan kepada manusia tidak diwujudkan dalam bentuk simbol-simbol dan institusi yang tidak tersentuh oleh akuntabilitas dan perubahan. Sapaan Tuhan kepada manusia, tambah Abou El fadl, lebih ditujukan pada hati manusia, bukan institusi mereka yang justru institusi tersebut terkadang bisa melukai Tuhan. ${ }^{60}$

3. Keadilan Sosial

Keadilan merupakan salah satu ekspresi dan tujuan hak-hak asasi manusia. Karena itu berbicara tentang keadilan sosial berarti berbicara tentang pemenuhan hak-hak fundamental manusia secara individual tanpa pembedaaan. MenurutAbou EI Fadl, wacana dan penerapan hak asasi manusia dalam masyarakat muslim mempunyai tantangan yang serupa dengan demokrasi. Sistem demokrasi menurutnya mengandaikan perlindungan dan penguatan HAM.

Dalam wacana al-Qur'an, adil merupakan sifat wajib Tuhan dan kewajiban manusia dalam berinteraksi dengan sesamanya. Keragaman penciptaan manusia dari sisi jenis kelamin, ras, agama dan kebangsaan dimaksudkan agar manusia membutuhkan kerja sama sosial dalam rangka menegakkan dan memperoleh keadilan. Kemajemukan dalam penciptaan bukan untuk saling mendominasi dan menyatakan diri sebagai superior atas yang lain. ${ }^{61}$

Persoalan mendasar dalam wacana keadilan dan fiqih adalah apakah hukum yang mendefinisikan keadilan atau sebaliknya keadilan yang mendefinisikan hukum. J ika yang

\footnotetext{
${ }^{58}$ Ibid., 5.

${ }^{59}$ Lihat, http://www.motherjones.com/mojoblog/archives/2007/11/6173_tancredo_go_boo.html

${ }^{60}$ Abou El Fadl, Selamatkan Islam, 234-236.

${ }^{61}$ Abou El Fadl, "The Human Rights Comitment in Modern Islam", dalam Runzo et.al., Human Rights and Responsibilities in the World Religions, 328.
} 
pertama, maka apapun yang dianggap sebagai hukum Tuhan adalah bernilai dan bersubstansikan keadilan. Dan jika yang kedua, maka apapun tuntutan keadilan, itulah hukum Tuhan. Pada kenyataannya, masyarakat muslim mempunyai cita-cita menerapkan hukum Tuhan. ${ }^{62}$

Menurut Abou El Fadl, mengimplementasikan aturan hukum yang bersifat legal, walaupun aturan tersebut merupakan produk dari interpretasi terhadap teks yang bersifat divine, tidaklah cukup untuk memperoleh persepsi yang jenuin terhadap the other, terhadap kasih sayang atau terhadap keadilan. Karenanya diperlukan perubahan paradigma, bahwa prinsip-prinsip kasih sayang dan keadilan seharusnya menjadi substansi primer aturan hukum yang diderivasi dari teks. Menurut paradigma ini, Tuhan adalah pemilik kedaulatan yang merupakan sumber dan pusat auto ritas, akan tetapi kemudian dalam konteks kemanusiaan, Tuhan mendelegasikannya kepada manusia untuk menggali cita keadilan Tuhan untuk diterapkan dalam realitas kebumian. ${ }^{63}$

Dalam wacana para Yuris, tidak mungkin untuk memperoleh keadilan kecuali setiap pemilik hak (hæqq) diberi jaminan atas haknya tersebut. Pada prinsipnya Tuhan mempunyai hak tertentu, manusia juga mempunyai hak dan keduanya sharing dalam beberapa hak tertentu. Karena itu penting dalam hal ini mengakui akan adanya hak (eksistensi hak), memahami siapa pemilik hak tersebut dan akhirnya memberi kebebasan kepada pemilik hak untuk menikmati dan mendayagunakan haknya tersebut. ${ }^{64}$

Di antara isu sensitif terkait dengan permasalahan keadilan sosial dalam tradisi Islam adalah tentang hak-hak mino ritas dan perempuan. Berkaitan dengan dengan pertama, Abou El Fadl menegaskan bahwa tidak boleh ada tirani mayoritas terhadap minoritas, baik minoritas agama, etnis dan yang lainnya. Ketika berbicara tentang demokrasi dan HAM, ia mengatakan bahwa harus ada sistem konstitusi sebagai parameter tidak adanya tirani. Dalam hal ini suara mayoritas dihormati sejauh tidak melanggar sistem konstitusi. Sistem konstitusi yang menjamin hak minoritas ini hendaknya dikembalikan pada prinsip-prinsip etis dan moral Islam. ${ }^{65}$

Abou El Fadl juga mempunyai concern terhadap ketimpangan relasi laki-laki dan perempuan, khususnya dalam budaya masyarakat puritan. Dalam hal ini ia secara khusus menjadikan persoalan penafsiran bias gender dalam fatwa-fatwa keagamaan yang dikeluarkan oleh CRLO (Council for Scientific Reseach and Legal O pinion), lembaga resmi Arab Saudi yang diberi mandat mengeluarkan fatwa sebagai obyek studinya. Fatwa-fatwa terkait dengan persoalan wanita ${ }^{66}$ dinilai mendegradasikan harkat wanita dan diklaim sebagai kehendak teks. Karena itulah dalam studinya tersebut Abou EI Fadl merasa berkepentingan untuk mengkaji dan mensosialisakan signifikansi hermeneutika dalam studi keislaman. Fiqih pada dasarnya adalah upaya menemukan dan menetapkan makna teks dan hermeneutika

\footnotetext{
62 Ibid., 329.

${ }^{63}$ Ibid., 331.

${ }^{64} \mathrm{Ibid}$.

${ }^{65} \mathrm{Abou}$ El Fadl, Selamatkan Islam, 233.

${ }^{66}$ Fatwa-fatwa tersebut antara lain berisi; larangan perempuan mengemudikan mobil, pembatasan wanita bekerja, ketaatan tanpa reserve kepada suami dan anjuran kepada istri untuk bersabar menghadapi perlakuan buruk suami serta fatwa-fatwa lain yang merendahkan. Lihat A bou El Fadl, Atas Nama Tuhan, 385.
} 
bermaksud melakukan humanisasi terhadap penetapan makna teks dengan membuat konstruksi yang berimbang antara Pengarang, teks dan pembaca serta lebih mempertimbangkan moralitas.

Sebagaimana pembedaan antara shari'ah yang bersifat ideal/abadi dan fiqih sebagai upaya menggapai yang ideal tersebut, relasi laki-laki dan wanita dalam cita-cita sharisahtadalah bercorak moralitas, yakni keadilan. Keadilan menuntut kesederajatan dalam hal nilai, kelayakan dan kesempatan. ${ }^{67}$

\section{Menimbang Konsepsi Fiqih Humanistik Abou El Fadl}

Ibn Khaldun, lewat teori sosiologinya menyatakan bahwa al-Rajul ibn bi'ætih yang artinya "Seseorang adalah anak zaman dari lingkungannya". Itu maknanya bahwa karakteristik pemikiran manusia tak terlepas dari kondisi sosial budaya yang melingkupinya, ia menjadi background bagi lahirnya frame pemikiran seseorang. Pikiran manusia selalu dipengaruhi oleh sikap dan emosi personal, pada level pertama, afiliasi kelas dan internalisasi budaya sekitar pada level kedua dan ketiga. ${ }^{68}$

Sebagaimana terpotret dalam biografinya, Abou El Fadl besar dan mengenyam pendidikan tingginya, meniti karir dan berdomisili di Amerika Serikat, sebuah negara yang konsen terhadap kebebasan, demokrasi dan hak asasi manusia. Dengan basis sosial dan budaya tersebut berpengaruh terhadap mental production Abou EI Fadl, dalam hal ini pemikiran fiqihnya yang bersifat humanistik. Pengalaman budaya, perjalanan intelektual dan riwayat kehidupan personalnya mempunyai relasi yang bersifat kausal dengan pemikirannya. Karena itu sebagian pihak memberikan klaim bahwa pemikirannya "bias", budaya dan nilai Barat. Persoalan yang substansial sebenarnya tidak terletak pada apakah pemikirannya bias Barat atau tidak. Karena memang dalam konteks sosiologi pengetahuan semua ide, pemikiran, keyakinan, dan dogma tidak terlepas dari bias. Barry Barnes dan David Bloor menyatakan: there are no context-free or super-cultural norms of rationality. ${ }^{69}$ Dalam hal ini konteks sosial dan rasionalitas tidak perlu untuk dipertentangkan.

Pertanyaan yang substansial terhadap pemikiran keagamaan dan fiqih era kontemporer adalah apakah ia pro-human atau tidak. Ketika pemikiran dan doktrin keagamaan dalam aplikasinya dinilai tidak manusiawi dipastikan telah terjadi deviasi dari cita ideal agama. Abou EI Fadl gelisah dengan deviasi tersebut yang mewujud dalam fenomena fundamentalisme dan radikalisme kelompok Puritan. Kelompok ini dipenuhi dengan perasaan utopis tentang kelompok terbaik dan klaim mewakili otoritas Tuhan justru dengan melakukan praktek kekerasan dan menindas hak asasi manusia.

Konsepsi-konsepsi fiqih humanistik Abou El Fadl pada dasarnya juga usaha harmonisasi doktrin dan praktek fiqhiyah dengan tuntutan era global. Sebagaimana pengakuannya sendiri,

\footnotetext{
${ }^{67}$ Abou El Fadl, Selamatkan Islam, 313.

${ }^{68}$ Dikutip oleh M. Ridlwan H ambali "H asan Hanafi ; Dari Islam "kiri", Revitalisasi Turath,, hingga Oksidentalisme", dalam Islam Garda Depan; Mosaik Pemikiran Timur Tengah (Bandung: Mizan, 2001), 218. Lihat juga Fuad Baali dan Ali Wardi, Ibn Khaldun and Islamic Thought-Style; a Social Perspective (America: G.K. Hall and Co. Boston, 1981), viii.

${ }^{69}$ Lihat "Social E pistemology" dalam http://plato.stanford.edu/entries/epistemology-social/ (akses 14 A pril 2008).
} 
pendekatan Abou El Fadl terhadap hukum lebih ditekankan pada dinamik antara hukum dan masyarakat - fokus bahwa hukum merefleksikan pencarian identitas dan definisi kedirian. ${ }^{70} \mathrm{Era}$ kontemporer yang sering kali disebut dengan global village menuntut adanya perubahan paradigma fiqih ke arah yang lebih progresif. Pola berfiqih yang hanya mengidealisasikan masa lalu akan bersifat a-historis dan tidak peka terhadap problem kemanusiaan kontemporer. G lobal village adalah realitas yang tak bisa dihindari. Ketika kehidupan manusia sudah tidak lagi tersekatsekat dalam bingkai geografis, kebangsaan, ras dan agama, maka konsekuensinya muncul fenomena global ethic. Etika global dianggap lebih bisa menyatukan manusia dan mengayomi persona manusia di tengah iklim kemajemukan dan pluralisme. Etika model inilah yang penulis sebut dengan humanisme. la bukan agama baru, tapi ia bisa bersandar pada nilai, moralitas, dan tradisi Islam. Hal ini merupakan titik temu (kalimah sawa') agama-agama. Humanisme berusaha menarik konsep kemaslahatan dalam konteks yang lebih luas dan tidak terjebak pada internal komunitas agama Islam saja. Dalam tradisi fiqih dikenal konsep al-adami,yyakni konsep kesatuan manusia yang dirujukkan pada Nabi Adam. Al-Adami adalah manusia baik dalam pengertian insan, bashar dan sakhs, M Menariknya adalah bahwa para Yuris berkonsensus terhadap wajibnya penghormatan kepada al-adami dalam kapasitasnya sebagai manusia tanpa melihat perbedaan jenis kelamin, agama dan yang lainnya sebagaimana teks menyatakan wa laqad karramna bani adam..$^{71}$

Sebagimana pemikiran tidak bersifat value-free, ide-ide Abou El fadl mempunyai fungsifungsi baik yang bersifat manifest atau latent. Sebagaimana yang dinyatakan secara lantang, apa yang dilakukan adalah counter-jihad terhadap praktek-praktek dehumanistik kelompok puritan. Counter-jihad tersebut dilakukan untuk merebut kembali dimensi Islam yang hilang dalam kekuatan dan gerakan kelompok puritan. Kelompok puritan menurutnya telah kehilangan otentisitas dan mereduksi kekayaan khazanah intelektual Islam klasik demi kepentingankepentingan yang bersifat ideologis. Otentisitas dan kekayaan tradisi tersebut menurutnya adalah dinamika intelektual, pengakuan terhadap ikhtilafdalam fiqih, dan kedalaman spiritualitas yang bersenyawa dengan praktek-praktek ritual. Abou El Fadl mengajak harkening back to tradition untuk selanjutnya menuju pada nilai-nilai moderat dalam Islam. ${ }^{72}$ Khazanah tradisi pada masa masa lalu terbukti telah memarjinalkan kelompok puritan. Pada dasarnya fiqih mempunyai etos yang progresif, dinamis dan egaliter. A kan tetapi etosyang sebelumnya dimediasi oleh ahli fiqih klasik mandek karena direbut oleh kaum puritan yang lebih mengedepankan kemapanan (status quo), stabilitas dan kesatuan. Ini terjadi karena, menurut Abou EI Fadl, semakin terpusatnya kekuasaan negara, ${ }^{73}$ diadopsinya sistem hukum perdata civil law ${ }^{74}$ birokrasi negara yang

70 "The Law and Beyond", dalam UCLA School Of Law; The Magazine of School of Law (Vol. 25, N0. 1, Fall 2001), 24.

${ }^{71}$ Lihat, "Adamis dalam al-M awsu'ah al-Fiqhiyah al-Kuwaytiyah (Kuwayt: t.n.p., t.t.), 8-9.

${ }^{72}$ Dialog Mother J ones dengan Abou EIFad Idalam http://www.motherjones.com/mojoblog/archives/2007/ 11/6173 tancredo go_boo.html

${ }_{73}$ Terpusatnya kekuasaan negara antara lain bisa dilihat dari semakin sentral dan despotiknya negara dalam mengontrol kehidupan beragama, nasionalisasi wakaf dan kontrol ketat pendidikan adalah sebagian contohnya.

${ }^{74} \mathrm{C}$ ivil law adalah sistem hukum Prancis yang bersandar pada struktur hirarkis yang terpusat yang secara tegas dan teoritis menerapkan sebuah sistem hukum yang padu. Perangkat dasar sistem civil law adalah aturan-aturan hukum yang dikodifikasikan secara sistematis. Sistem ini memojokkan fiqh sebagai tradisi keragaman pandangan hukum. 
hegemonik ${ }^{75}$ dan pengalaman kolonialisme yang tidak mengenakkan. ${ }^{76}$

J adi yang dikampanyekan Abou El fadl adalah pola berfiqih yang moderat tanpa tercerabut dari akar tradisi fiqih masa lalu. Abou El Fadl sendiri dipercaya mempunyai otoritas dalam bidang fiqih karena penguasaannya pada tradisi dan literatur klasik. Ia belajar teks dan tradisi keislaman selama 30 tahun, dan hari-harinya dipakai untuk membaca koleksi literatur dan manuskrip Islam klasiknya yang berjumlah 20.000 judul. ${ }^{77}$ Selain itu ia ingin mendobrak dominasi. Kelompok puritan dengan pola ber-fiqih yang tekstual memang minoritas dari sisi kuantitas. Akan tetapi suara mereka terbukti lebih menggema dan dominan dari kelompok silent majority.

Pemikiran fiqih Abou El fadl sebagaimana terbaca dalam tulisan-tulisannya memang tidak memberikan alternatif baru metodologi istinbatyhukum baru. Akan tetapi paradigmanya yang bersifat humanistik dalam mengkaji fiqih patut mendapatkan apresiasi tersendiri. Komitmen terhadap moralitas dalam studi fiqih bagaimanapun lebih signifikan dari pada sekedar terjebak dalam mekanisme dan teknikalisme perangkat metodologi hukum, bukankah pepatah mengatakan the man behind the gun?

\section{Penutup}

Fiqih adalah the epitome of Islamic sciences. Pengaruh keilmuan ini terhadap perilaku umat tidak bisa diragukan lagi. Sebagaimana poros keilmuan fiqih disandarkan pada teks, maka studi terhadap keilmuan ini dengan melibatkan keilmuan yang relevan adalah kebutuhan yang sangat mendasar, termasuk dalam hal ini adalah hermeneutika. Fiqih sebagai bagian dari ilmu sosial tidak bisa didekati dengan positivistik, karena itu selain dukungan keilmuan yang relevan terhadap studi fiqih, paradigma humanis perlu dikembangkan. Ini dilakukan dalam rangka merespon tuntutan perkembangan dunia yang semakin menglobal dengan realitas kemanusiaan yang majemuk.

Humanisme sebagai sebuah gerakan literer dan program budaya sangat relevan sebagai perspektif dalam studi fiqih sebagaimana Islam juga tidak bisa lepas dari teks dan program budaya humanisme yang bersifat etis sesuai dengan ideal-moral Islam.

Humanisme dalam pemaknaan di atas telah dengan cerdas dicangkokkan oleh Abou EI Fadl dalam kajian Fiqihnya. Kajian fiqihnya bermuara pada ide pluralisme, demokrasi dan keadilan sosial sebagaimana ide-ide ini secara par excellence diusung oleh proyek humanisme. Kerja Abou EI Fadl dalam hal ini menunggu follow up dari sarjana-sarjana lain dalam rangka menyemaikan dan merawat harmoni kehidupan. Semoga!

\footnotetext{
${ }^{75}$ Birokrasi yang hegemonik mengontrol para ahli hukum dan menjadikan sebagian dari mereka - dengan pola rekruitmen yang tidak transparan - sebagai pegawai-pegawai yang dibayar.

${ }^{76}$ Kolonialisme mengeluarkan kebijakan pengadministrasian lembaga tradisi untuk menjinakkannya. Pengalaman tersebut masih dirasakan sampai sekarang dan digantikan perannya oleh pemerintahan negara-negara muslim yang despotik. Lihat M. Abou EI Fadl, Atas Nama Tuhan, 5.

${ }_{77}$ Bandingkan dengan Teresa Watanabe, "Battling Islamic Puritans," dalam Los Angeles Times (2 J anuari 2002).
} 


\section{Daftar Rujukan:}

1. Sumber Buku dan Majalah:

al-J abiri, 'A bid. Syuro; Tradisi, Partikularitas dan Universalitas. Yogyakarta: LKiS, 2003.

Baali, Fuad dan Ali Wardi. Ibn Khaldun And Islamic Thought-Styles; A Social Perspective. Massachusetts: G.K. Hall and Co. Boston, 1981.

Bonner, Michael. J ihad in Islamic History. Princeton: Princeton University Press, 2006.

El Fadl, Abou. "The Human Rights Comitment in Modern Islam", dalam Runzo et.al., Human Rights and Responsibilities in the World Religions.

. Atas Nama Tuhan; dari Fikih Otoriter ke Fikih O toritatif. Pent. R. Cecep Lukman

Yasin. J akarta: Serambi, 2004.

. Cita dan Fakta Toleransi Islam, terj. Heru Prasetia. Bandung: Mizan, 2003.

. Islam and the Challenge of Democracy. Princeton: Princeton University Press, 2004.

(sample chapter).

. Selamatkan Islam dari Muslim Puritan. terj. H elmi Mustofa. J akarta: Serambi, 2006.

Hambali, M. Ridlwan. "Hasan Hanafi ; Dari Islam "kiri", Revitalisasi Turath,, hingga

O ksidentalisme", dalam Islam Garda Depan; Mosaik Pemikiran Timur Tengah. Bandung:

Mizan, 2001

Husnayn, Mustafa Muhammad. al-Siyasah al-J inaiłah fi al-Tashri'`al-Islami>M ekah: J ami'ah alImam Muhammad b. Sa'ud al-Islamizah, 1984.

Izetbegovic, Alija 'Ali. 'The Meaning of Humanism' dalam Marcel A. Boisard, Humanism in Islam. Kuala Lumpur: Islamic Book Trust, 2003.

J ohn L. Esposito, a respon to The Place of Tolerance in Islam (O riginally published in the Februaryl March 2002 issue of Boston Review).

Kraemer, J ohn L. Renaissance Islam. Terj. Asep Saifullah. Bandung: Mizan, 2003.

Kuntowijoyo. Islam sebagai Ilmu; Epistemologi, M etodologi dan Etika. Yogyakarta: Tiara Wacana, 2006.

Levine, Peter. Nietzsche and the Modern C risis of the Humanities. New York: State University of New York Press, 1995.

Magnis-Suseno, Franz. Etika Kebangsaan Etika Kemanusiaan. Yogykarta: Kanisius, 2008.

Moosa, Ebrahim. Islam Progresif; Refleksi Dilematis tentang HAM, Modernitas dan Hak-Hak

Perempuan di dalam Hukum Islam. Yogyakarta: LKiS, 2004.

Smith, Tony. Concise Oxford English Dictionary Eleventh Edition. Software atau digital dictionary berdasar text: Oxford University Press, 2004

Teresa Watanabe, "Battling Islamic Puritans," dalam Los Angeles Times (2 J anuari 2002).

Tjaya, Thomas Hidya. Humanisme dan Skolatisisme; Sebuah Debat. Yogyakarta: Kanisius, 2004. UCLA School of Law; The Magazine of School of Law (Vol. 25, N0. 1, Fall 2001), 24.

Zeitlin, Irving M. Ideology and Development of Sociological Theory. London: Prentice-Hall, 1981.

2. Sumber Web:

http://en.wikipedia.org/wiki// izya (akses 3 J uni 2008) 
34 Pluralisme, Demokrasi dan Keadilan Sosial dalam Konsepsi Fiqih Humanistik Abou El Fadl

http://www.motherjones.com/mojoblog/archives/2007/11/6173_tancredo_go_boo.html http://bostonreview.mit.edu/BR26.6/elfadl.html

http://www.scholarofthehouse.org/oninma.html, (akses 31/12/2007).

The Daily Texan on Line.

http://www.sinarharapan.co.id/berita/0310/15/opi01.html, (Akses 13 J an 2008).

http://plato.stanford.edu/entries/epistemology-social/ (akses 14 April 2008).

Al-Mostafa.com. al-Mawsu'ah al-Fiqihiyyah al-Kuwaytiyyah. Kuwayt: t.n.p., t.t. 